\title{
Motor racing, tobacco company sponsorship, barcodes and alibi marketing
}

\author{
Bruce Grant-Braham, ${ }^{1}$ John Britton ${ }^{2}$
}

'Motor Sport Research Group, School of Tourism.

Bournemouth University, Poole, Dorset, UK

${ }^{2}$ UK Centre for Tobacco Control Studies, Division of

Epidemiology and Public Health, University of Nottingham,

Nottingham, UK

\section{Correspondence to}

Dr Bruce Grant-Braham Motor Sport Research Group, School of Tourism, Bournemouth University, Dorset House, Talbot Campus, Fern Barrow, Poole, Dorset BH12 5BB, UK; motorsport@bournemouth.ac.uk

Received 2 February 2011 Accepted 11 July 2011

Published Online First 5 August 2012

\section{(D) ULOCKID}

This paper is freely available online under the BMJ Journals unlocked scheme, see http://tc. bmj.com/site/about/unlocked. xhtml

\section{ABSTRACT}

Background Sponsorship of Formula One (F1) motor racing, which has been used as an indirect medium of tobacco advertising for several decades, was prohibited by the 2005 European Union Tobacco Advertising Directive. Most F1 tobacco sponsorship of motor racing in the EU has since ceased, with the exception of the Scuderia Ferrari team, which continues to be funded by Philip Morris. In 2007, the Marlboro logo on Ferrari cars and other race regalia was replaced by an evolving 'barcode' design, which Ferrari later claimed was part of the livery of the car, and not a Marlboro advertisement.

Objective To determine whether the 'barcode' graphics used by Ferrari represent 'alibi' Marlboro advertising.

Methods Academic and grey literature, and online tobacco industry document archives, were searched using terms relevant to tobacco marketing and motorsport.

Results Tobacco sponsorship of F1 motor racing began in 1968, and Philip Morris has sponsored F1 teams since 1972. Phillip Morris first used a 'barcode' design, comprising red vertical parallel lines below the word Marlboro on the British Racing Motors F1 car in 1972. Vertical or horizontal 'barcode' designs have been used in this way, latterly without the word Marlboro, ever since. The modern 'barcode' logos occupied the same position on cars and drivers' clothing as conventional Marlboro logos in the past. The shared use of red colour by Marlboro and Ferrari is also recognised by Philip Morris as a means of promoting brand association between Marlboro and Ferrari.

Conclusion The Ferrari 'barcode' designs are alibi Marlboro logos and hence constitute advertising prohibited by the 2005 EU Tobacco Advertising Directive.

\section{INTRODUCTION}

Advertising is the primary means by which commercial companies promote their products and services. Advertising can be direct, as in overt paidfor space in broadcast, print and other media, or indirect, through media reporting of events or images containing direct advertising. Both approaches have been exploited by tobacco companies for many years, but as a result of increasing restrictions on direct advertising of tobacco on television and in other media in many countries since the late 1960s, tobacco companies have become increasingly reliant on indirect methods to promote their products. ${ }^{1-5}$

One of the most enduring and successful forms of indirect advertising, particularly in relation to promoting uptake of smoking among children, is sponsorship of sport. ${ }^{6}$ This is especially true of motor racing, and particularly Formula One (F1).
Over recent decades, an increasing number of national governments have acted to prevent this method of tobacco promotion by prohibiting the display of tobacco advertising in motor racing and other sports, and in July 2005 tobacco sponsorship of cross-border events or activities was explicitly prohibited across all EU member states by the EU Tobacco Advertising Directive. ${ }^{7}$ Most tobacco sponsorship of F1, at least in Europe, then came to an end, with the exception of Marlboro sponsorship of the Scuderia Ferrari F1 team by Philip Morris, which has continued to date. In 2007, the Marlboro logo on Ferrari F1 cars, drivers' race suits and helmets, and in the Scuderia Ferrari team logo, was, with the exception of the 2007 Bahrain, Monaco and Chinese F1 races, substituted with a vertical stripe 'barcode' design which, over successive years on cars and other livery, has become increasingly complex.

Ferrari has claimed that the barcode designs are simply part of the livery of the car, and not a marketing tool. ${ }^{8}$ We have therefore reviewed the history of tobacco industry sponsorship of F1 motor racing and searched tobacco industry document archives to determine whether this claim can be substantiated.

\section{METHODS}

The historical context of motor racing sponsorship was sourced from Grant-Braham's earlier work ${ }^{9}$ and augmented between May and July 2010 by iterative searches of tobacco industry documents in the Legacy Tobacco Documents Library (http:// legacy.library.ucsf.edu), the British American Tobacco (BAT) Documents Archive (http://bat. library.ucsf.edu) and the UK Tobacco Industry Advertising Documents Database (http://www tobaccopapers.com) for terms associated with both tobacco and motor racing. These initially comprised motor racing, auto racing, trademark, logo and barcode, and searches on these terms identified others such as Marlboro, Philip Morris, red roof, McLaren (F1 Team), Ferrari (F1 Team), Penske (IndyCar Team), livery, subliminal marketing, indirect marketing and dark markets, which were included in subsequent searches. We also included the names of specific individuals identified from retrieved documents as having been involved in tobacco product marketing or in administering the sponsorship of teams or championships in motor racing. More than 1200 documents were accessed online and of these 200 proved relevant for detailed analysis. In accordance with previous recommendations, we have, where possible, attempted to triangulate industry document findings with data from other sources. ${ }^{10}$ 


\section{RESULTS}

\section{Sponsorship in motor racing}

The F1 World Championship for Drivers and Constructors was established in 1950 and has since been contested annually through a worldwide series of Grand Prix races. In the early years of the competition, commercial advertising and sponsorship were restricted and cars tended to race in the sport's national colours. However, in 1968 these restrictions were lifted, and in the 1968 South African Grand Prix a car raced carrying the Rhodesian tobacco company Gunston cigarette brand livery. At the next F1 race at Jarama in Spain, Colin Chapman, who founded the Lotus F1 Team, and is credited as the pioneer of tobacco sponsorship in F1, paired Team Lotus with Imperial Tobacco's Gold Leaf cigarette brand in what proved to be the beginning of a long association between $\mathrm{F} 1$ and tobacco finance. ${ }^{11-13}$ The incorporation of the sponsor's name into that of the racing team, Gold Leaf Team Lotus, and the complete branding of the racing cars in a commercial livery, was the first example in F1 of a practice that became known as 'brandstanding, ${ }^{14}$ Lotus went on to create a prime example of brandstanding in the form of the Lotus John Player Special cigarette brand promotion, "which is still associated in many people's minds with the sport some years after it came to an end' ${ }^{15}$ That the product being promoted had no obvious link with the sport itself was a landmark development, demonstrating 'the recognition by commercial organisations that at the international level the spectacle of a Grand Prix ... could be used for promotional and advertising purposes'. ${ }^{16}$

\section{F1: a global sport}

From the outset, the F1 World Championship has been contested globally. Although at first the majority of Grand Prix races were held in Europe, locations in North and South America, Australia and Japan were soon included. As prohibition of tobacco advertising and sponsorship in the $\mathrm{EU}$ increased, the governing body of worldwide motorsport, the Federation Internationale Automobile, began to adopt venues in European countries outside the EU, such as Turkey, and in China and Malaysia. ${ }^{17}$ Holding races in the Pacific Rim suited the tobacco sponsors particularly well because these were growing markets for cigarettes and because tobacco logos were then accepted on television in these areas. ${ }^{18}$ The importance of retaining media exposure for branded cars was articulated by the President of Formula One Management, Bernie Ecclestone, in 2006:

\begin{abstract}
There's been this big push to keep races in which we can run with tobacco branding. According to the law in Italy, for example, we can run branded there-so it means that we keep two races. Same in Germany. So we've got races that maybe we wouldn't have had otherwise. ${ }^{19}$
\end{abstract}

\section{Strategies for 'dark markets'}

In the 1990s, BAT began to develop strategies for what it referred to as 'dark markets'-areas and countries in which tobacco promotion was restricted-by designing 'global dark market logos'. ${ }^{20-22}$ For example, the BAT 'dark market campaign' for its Silk Cut brand exploited the distinctive purple colour and silk association with the brand, which were described as 'focused equities that cannot be banned by legal restriction' and discussed under a technique heading of 'Brand Colours and Shapes'. ${ }^{23}$ Specific colours are associated with specific cigarette brands, such as purple for Silk Cut and red for Marlboro, and can be a core element of surreal marketing. ${ }^{24}$ In 1998, BAT created the 'European Going Dark Taskforce' to use 'Black Procedures' in addressing the implications for tobacco manufacturers of the adoption of the EU Tobacco Advertising Directive. ${ }^{25-27}$ Other tobacco companies took a similar approach: Philip Morris justified its motorsport sponsorship on the back of TV coverage as 'particularly important in restricted markets'. ${ }^{28}$

\section{Marlboro sponsorship in F1}

Philip Morris' Marlboro cigarette brand first appeared in the USA in 1924 and, having originally being aimed at women by offering an option of a 'Red Beauty Tip' to hide lipstick marks, has always been associated with the colour red. In 1954, Marlboro was repositioned as a masculine and full-flavour cigarette with 'roof-top' graphics on the packaging. Marlboro Reds were launched in $1985^{29}$

Philip Morris began sponsoring F1 with the British Racing Motors (BRM) team in 1972 with the creation of 'Marlboro BRM', and was probably the first F1 sponsor to recognise the importance of leveraging this involvement by creating 'marketing projects'. For example, in 1972 the company flew journalists to the team's French launch, at which the racing car emerged from a giant Marlboro cigarette packet, achieving widespread media publicity (figure 1).

In 1974, Marlboro sponsorship was moved from BRM to the McLaren F1 team, establishing an association that would continue for 23 years. ${ }^{14}$ The success of this enterprise was recognised, for example, by Philip Morris in Australia where the Marlboro market share was low but brand awareness was 'comparatively very high at $32 \%$... as a result of Marlboro's sponsorship of the McLaren (F1) Team and Team Roberts (motorcycle racing) ${ }^{30}$ Marlboro's penetration of the Japanese market increased following the broadcasting of Marlboro sponsored F1 auto races in the late 1980s. ${ }^{31}$

In 1991, Philip Morris widened its F1 activities by adding Marlboro sponsorship of Ferrari, and sponsored both teams until 1996, when the McLaren sponsorship ended. The association between Marlboro and Ferrari continues to the present day, with a current sponsorship agreement that extends to 2011. ${ }^{32}$

The Ferrari F1 team traditionally races in Italy's historic national motor racing colour, red. Philip Morris documents reveal that the company has long recognised the importance of association with Ferrari, and the red colour schemes shared by Ferrari and the Marlboro brand. Only once in F1 has Marlboro made use of a colour other than red, at the 1986 Portuguese F1 Grand Prix, when McLaren ran one car in a gold and white

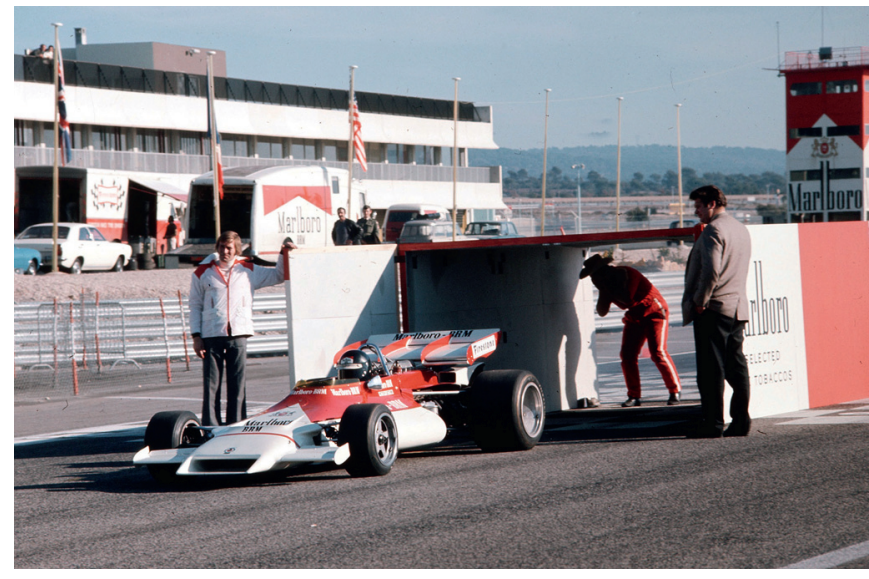

Figure 1 Marlboro branded BRM F1 car emerging from a mock-up of a giant Marlboro cigarette pack in 1972 (LAT Photographic). 

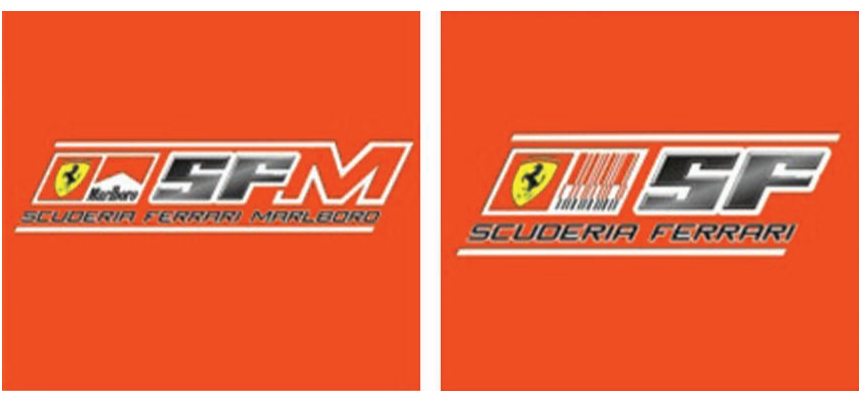

Figure 2 Ferrari F1 team names and logos, 2007 and 2010.

livery. This was to promote Philip Morris' new Marlboro Lights brand of cigarettes. The colour did not work on television and the experiment was never repeated. ${ }^{33}$

Although it did not come into the market, Philip Morris also researched the potential of a Ferrari cigarette brand in 1986, ${ }^{34-39}$ with the intention of making use of the motor racing heritage of the Ferrari trademark and capitalising on the association with motor racing. Packaging would have used what were then 'the distinctive red and yellow Ferrari colours'. ${ }^{40} 41$ Ferrari's strong association with Marlboro was felt to be 'due in part to the colour of the Ferrari car (red)'. ${ }^{42}$ By 1991, one of Philip Morris Italy's marketing objectives was to 'attribute to Marlboro some of the positive characteristics of the Ferrari trademark'. 4344

Between 1997 and 2010, the word Marlboro was included in the Ferrari racing team name (Scuderia Ferrari Marlboro), and a Marlboro logo was also incorporated into the team logo. When the EU Tobacco Advertising Directive came into force, Philip Morris stated:

It [the Marlboro sponsorship] is going to comply with the rules and regulations wherever we do business. There are countries where tobacco sponsorship is obviously not allowed. In those countries we will continue to support Ferrari without branding. ${ }^{32}$

In due course, the word Marlboro was dropped from the team name, and the logo replaced with a barcode design (figure 2).

\section{Marlboro trademarks and the barcode}

Philip Morris actively administers, protects and defends the Marlboro brand trademarks, describing its Red Roof trademark as being 'among the most famous and valuable product identifiers in the world'. ${ }^{45}$ Philip Morris Products currently owns a number of UK trademark registrations related to cigarettes, most of which use the 'Red Roof' theme (figure 3). ${ }^{46-49}$ In 1982, the company registered a trademark for non-tobacco products that incorporated the 'Roof' design but substituted two horizontal lines for the word Marlboro. ${ }^{50}$

The red roof design was used extensively in the livery of McLaren's F1 cars, and on occasions the word Marlboro was substituted with McLaren (figure 4), probably in response to voluntary agreements on the sponsorship of sport by tobacco companies with various governments, which, as far as F1 is concerned, started in Germany in $1976 .{ }^{51}$ In the UK, for example, the fourth such voluntary agreement in 1995, 'placed restrictions relating to the display of [tobacco] sponsor's signs, the use of brand names or symbols at televised events' and did not permit 'the display of house or brand names or symbols on participants and officials, their vehicles and/or animals likely to come within the scope of the television cameras'. Participants were defined to include 'auxiliary personnel and mechanics'. ${ }^{52}$

Also in 1993, the word Marlboro under the red roof logo was on occasions substituted with seven black vertical stripes, as, for example, in the German Grand Prix (figure 5).

The 1993 Ferrari vertical stripe design had in fact been used in association with the word Marlboro on previous cars, in red on BRM F1 cars in 1972 and in black on McLaren F1 cars in 1988. However, the 1993 example used the parallel lines without, and apparently as a substitute for, the word Marlboro. These examples of the vertical stripe design and subsequent evolution into the modern 'barcode' logo are shown in figure 6.

By 2011, the modern barcode designs had completely replaced all conventional Marlboro logos on Ferrari cars, and also on drivers' racing suits and helmets in the locations specified by Philip Morris for Marlboro logos in earlier sponsorship agreements (figure 7). For example, in 1993 one such agreement specified that the driver would 'wear on his helmet and uniform during each series race in which he participates the Philip Morris supplied Marlboro identification', that this identification should comprise the 'Red Marlboro chevron and black lettering on white background' and that the identification should appear 'on the front of the uniform, the sleeves of the uniform, the rear of the uniform, and the helmet'.53

The use of the parallel line design as a substitute for a more conventional Marlboro logo was observed in several BAT documents, which reported that:

Current practice in the F1 environment shows that competitive brands develop alternative logos. These alternative logos are as close as legally possible to the brand logo. In the case of Philip Morris, letters are changed into straight black lines with different width. ${ }^{54-57}$

In one 1999 BAT internal note, the middle sentence is removed and replaced in handwriting with: Generally using the same colour scheme and those elements of the existing logo which are legally permitted. ${ }^{58}$

\section{The Ferrari defence of the barcode}

When challenged by a series of media reports in early 2010 that the barcode design was in reality a Marlboro logo, Ferrari responded that the so called barcode is an integral part of the livery of the car and of all images coordinated by the Scuderia, as can be seen from the fact it is modified every year, and,

Figure 3 A selection of Philip Morris trademarks registered in the UK 1956-82.

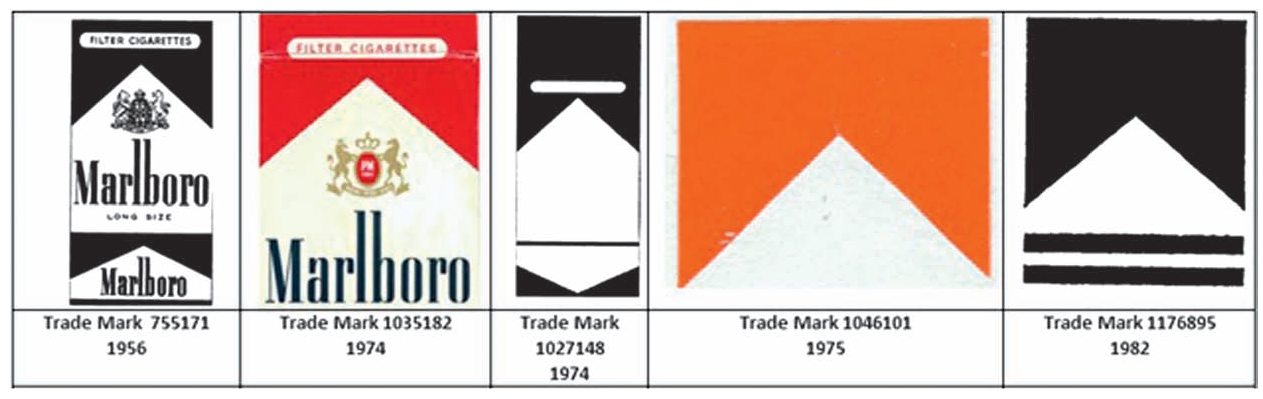




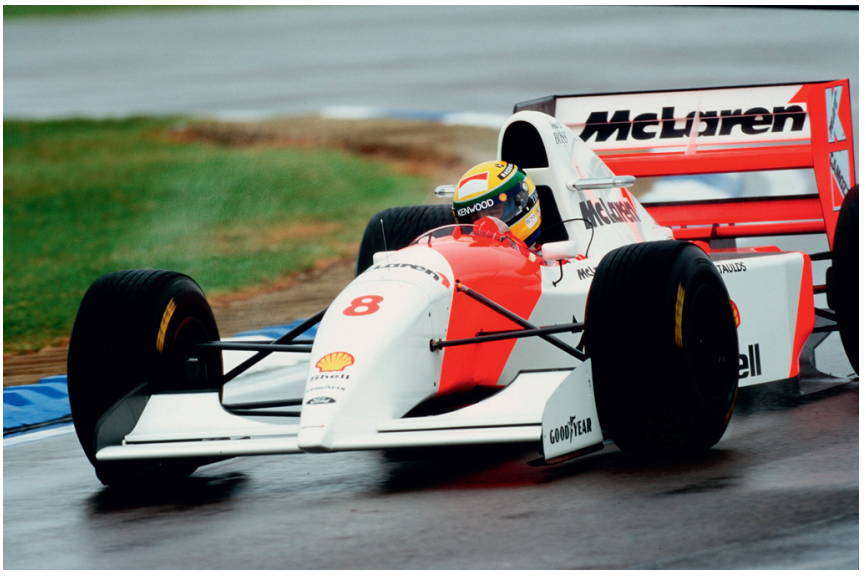

Figure 4 Substitution of Marlboro with McLaren on a McLaren F1 car in 1993 (LAT Photographic).

occasionally even during the season. Furthermore, if it was a case of advertising branding, Philip Morris would have to own a legal copyright on it'. ${ }^{59}$ An article on a motorsport website (http:// www.autosport.com/) quoted from a Scuderia Ferrari Marlboro press release, which said that criticism was 'based on two suppositions: that part of the graphics featured on the Formula 1 cars are reminiscent of the Marlboro logo and even that the red colour which is a traditional feature of our cars is a form of tobacco publicity...neither of these arguments have any scientific basis, as they rely on some alleged studies which have never been published in academic journals. But more importantly, they do not correspond to the truth'. ${ }^{6}$

\section{DISCUSSION}

Advertising and promotion are essential activities for companies seeking to maintain or increase the sales of a product, and tobacco companies have used both paid-for advertising and media coverage of sponsored activities to promote cigarettes for many years. However, the imposition of controls on the use of paid-for advertising has made alternative methods of gaining media publicity for brands and products particularly important to the tobacco industry, and sponsorship of F1 and other motorsports has proved particularly successful in this respect. As early as the 1970s, tobacco companies had 'realised that investment in sport offered a viable and effective means of recouping coverage they were increasingly debarred from achieving through conventional television advertising'. ${ }^{15}$ Analysis showed that the Marlboro brand name, for example, could be visible for as much as half of the total broadcast time of a race. ${ }^{6}$

Tobacco marketing has devised innovative ways to attach brand names, logos or identities to non-tobacco products using

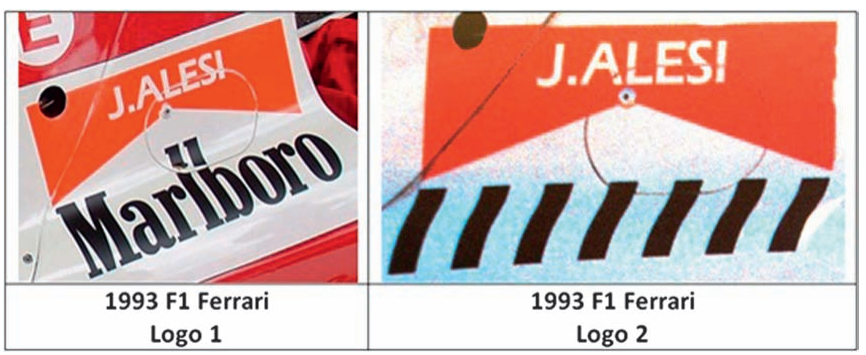

Figure 5 Two logos in identical positions on the 1993 season Ferrari F1 car.

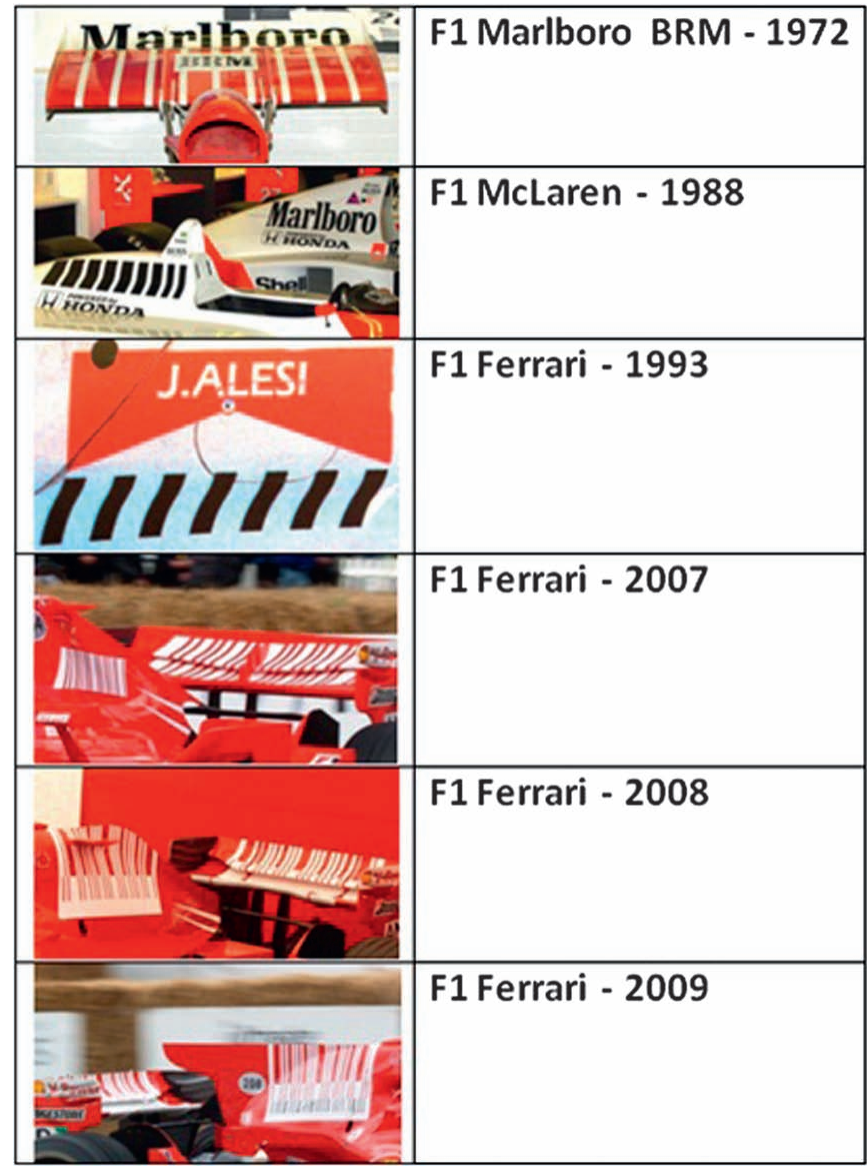

Figure 6 The evolution of the Marlboro barcode.

techniques known as 'trademark diversification' and 'alibi marketing' ${ }^{61}$ Trademark diversification involves the use of a cigarette brand name on the branding of other and typically unrelated products, such as clothing. ${ }^{62}$ Alibi marketing involves distilling a brand identity into its key components, such as the distinctive red and white colouring associated with the Marlboro brand, or the shade of purple used by Silk Cut, and using these to promote the brand in place of a conventional logo or trademark. ${ }^{63}$ This study was carried out to assess the validity of Ferrari's assertion that barcode design displayed on their F1

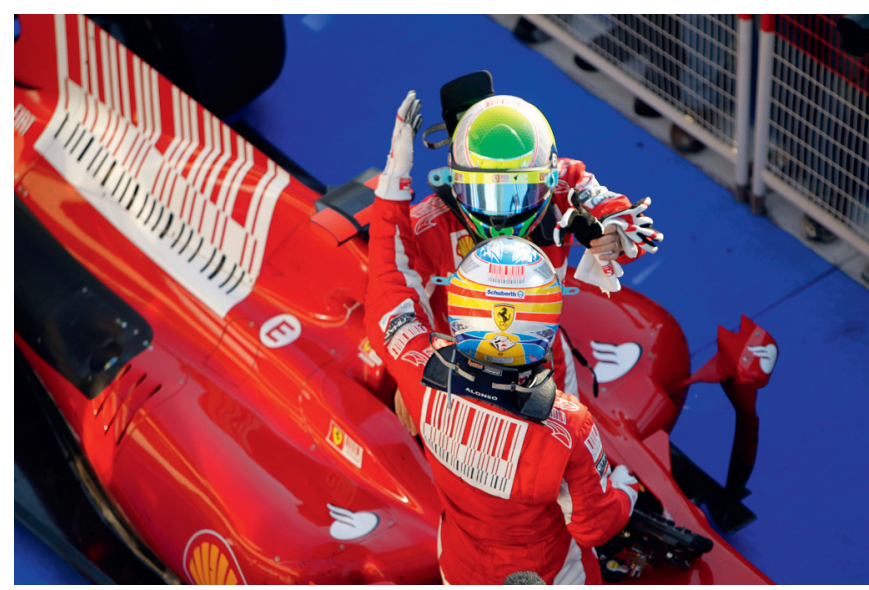

Figure 7 Marlboro 'barcodes' on both the Ferrari race car and the driver's clothing in early 2010 (LAT Photographic). 
racing cars, and also on drivers' suits, helmets and other locations, did not represent alibi Marlboro advertising.

Our findings demonstrate that Philip Morris has long recognised the importance of brand colours and shapes, and has in the past registered trademarks that include the red roof design without words, or with parallel lines in place of the word Marlboro. The company has also in the past referred to the importance of the shared use of the colour red by both Marlboro and Ferrari in the development of a new tobacco product. Our findings demonstrate that the use of a parallel vertical stripe design on racing cars, either in place of or in addition to the word Marlboro, dates back to the early 1970s, and also that the design evolved over that period into the complex logo used in the 2010 season Ferrari liveries. The barcode logos occupy precisely the same locations on the car and on drivers' clothing, as did the conventional Marlboro logos before the $2005 \mathrm{EU}$ directive. It is thus evident that the barcode logo is an alibi for the red roof trademark and Marlboro name. The likelihood is that this design is recognised and understood by consumers as a substitute for conventional Marlboro logos, and may even have come to represent a form of a shared joke between the advertiser and the consumer in an environment in which both know that overt advertising is not allowed. The $2005 \mathrm{EU}$ Directive refers to the use of alternative logos and advises that 'advertising means any form of commercial communication with the aim or direct or indirect effect of promoting a tobacco product'. ' In our view, the barcode design fits into this definition, and we note that Philip Morris' continued sponsorship of Ferrari ${ }^{64}$ appears to contravene the Directive. It would also contravene the comprehensive ban of all tobacco advertising, promotion and sponsorship, including cross-border activities, proposed by signatories to Article 13 of the Framework Convention on Tobacco Control. ${ }^{65}$

Cigarette marketers have two core goals: developing brand identity and entrenching ideas and feelings related to their products. ${ }^{24}{ }^{66}$ Tobacco marketers communicate image rather than information to establish a brand identity, which the consumer then adopts as an expression of personal identity. ${ }^{66}$ Although originally not obviously synergistic with motor racing, smoking and cigarettes do in fact share a great deal in common with the sport. In market research, F1 is characterised by descriptors consistent with a perception that the sport is international, expensive, glamorous, challenging, fast, furious, dangerous, and associated with living life to the full and living life on the edge. ${ }^{67}$ Marlboro perceives F1 racing as 'a modern-day dimension to the Marlboro Man. The image of Marlboro is very rugged, individualistic, heroic. And so is this style of auto racing. From an image standpoint, the fit is good' ${ }^{24}$ The Marlboro Man's masculine image has been found to appeal along with F1 racing to young Japanese men, as also does the overlap between the health risks of smoking and motor racing. ${ }^{31}$

The tobacco industry has been both creative and active in addressing dark or restricted markets and has used dark market logos in those countries where tobacco promotion has been discouraged. ${ }^{20-23}$ While Marlboro has made great use of the colour red, the literature shows that it is not alone in also making good use of focused equities such as colours and shapes. ${ }^{23}{ }^{29}$ Product recall is aided by a distinctive race car livery ideally in the same colour as the product's packaging. ${ }^{67} \mathrm{~F} 1$ Racing magazine reported that internal research had shown that Marlboro's red barcode created a stronger association with consumers than even the previous 'plain white chevron' taken to mean the 'Red Roof' trademark. ${ }^{68}$ The establishment of this brand identity through colour probably also increases the impact of the same colours in more direct tobacco product branding, as in the use of colour on cigarette packs, which are themselves an important communication device acting as an advertising medium. ${ }^{69}$ Cigarette brands are also perceived to gain credibility by being linked to less contentious products. ${ }^{70}$

When the barcode graphic was removed from the Scuderia Ferrari Marlboro F1 cars in response to complaints in early 2010, a Ferrari team press statement is quoted to have said that, 'together with Philip Morris International we have decided to modify the livery of our cars starting with the Barcelona Grand Prix' ${ }^{71}$ If the barcode was purely innocent livery, as Ferrari claimed, it is not clear why Marlboro's parent company, Philip Morris, was involved in the decision to remove it. This is particularly relevant in that title sponsors, such as Marlboro, usually pay for and are therefore entitled to the space in the prime positions on the race car. The consultation with Philip Morris may be explained by the allegation that the company pays Ferrari for control of the car's livery, within which they can then sell space to other companies. ${ }^{72}$ It appears highly unlikely that, given the commercial value of all space on the F1 car, and particularly the prime position on either side of the engine cover immediately behind the driver, and that such prime space has historically been used by a major sponsor, Philip Morris would elect to instead use that area for simple livery designs. Tellingly, in an editorial in the online magazine GP Week, Philip Morris' sponsorship chief Maurizio Arrivabene is quoted as describing the barcode as 'our logo'. ${ }^{64}$

The removal of the barcode from F1 cars in May 2010, and the removal of the barcode design from driver suits and helmets

\section{What is already known on this subject}

- Advertising of tobacco on Formula 1 (F1) race cars, and sponsorship of F1 by tobacco companies, was prohibited in the European Union (EU) by the 2005 EU Tobacco Advertising Directive.

- However, the Scuderia Ferrari F1 team has maintained a sponsorship agreement with Philip Morris and in recent years has substituted the Marlboro logo with an increasingly complex 'barcode' design.

- Scuderia Ferrari claim that the barcode design is part of the livery of the car, and is not a Marlboro logo or advertisement.

What this paper adds

- Philip Morris has used barcode designs on racing cars since 1972. These designs have been substituted for conventional logos in circumstances in which overt advertising has been prevented in the past ('dark markets').

- Philip Morris also recognise the shared use of the colour red as a means of promoting brand association between Marlboro and Ferrari.

- The barcode designs occupy exactly the same position on cars, drivers' clothing and other livery as was specified for the conventional Marlboro logo in past years. The barcode designs in fact represent 'alibi' marketing. This mode of advertising, and indeed Philip Morris' continued sponsorship of $F 1$ in the EU, appears to be in direct contravention of the 2005 Tobacco Advertising Directive. 
from the start of the 2011 season, represents the end of this particular manifestation of alibi marketing for Marlboro but is unlikely to represent the end of the practice. Indeed, a new 'team' logo has replaced the barcode for the 2011 season and appears in all the same locations. Scuderia Ferrari Marlboro is in a sponsorship arrangement with Philip Morris International at least until the end of the 2011 F1 season, and the team's official website continues to describe Philip Morris International as a team sponsor and to display the trademark Philip Morris crest. $^{73}$ It would appear that until tobacco money has been removed completely from F1 and indeed all other overt and covert sponsorship in areas the tobacco industry has been able to exploit for many years, ${ }^{74}$ the marketing of tobacco products through alibis and dark market techniques is likely to continue.

Funding This study was funded in part by the UK Centre for Tobacco Control Studies, with core funding from the British Heart Foundation, Cancer Research UK, Economic and Social Research Council, Medical Research Council and the Department of Health under the auspices of the UK Clinical Research Collaboration.

\section{Competing interests None.}

Provenance and peer review Not commissioned; externally peer reviewed.

\section{REFERENCES}

1. Meenaghan A. Commercial sponsorship. Eur J Mark 1983:7:5-73.

2. Head V. Successful Sponsorship. 2nd edn. Cambridge: Director Books, 1988:35

3. Thomas D. Welcome to the Piranha Club. The Mail on Sunday Review - Night \& Day 1995:46-50.

4. Crompton JL. The potential contributions of sports sponsorship in impacting the product adoption process. Manag Leisure 1996;1:199-212.

5. Helberg D. Butt out: an analysis of the FDA's proposed restrictions on cigarette advertising under the commercial speech doctrine. Loyola Los Angel Law Rev 1996:29:1219-72.

6. National Cancer Institute. Monograph 19, The Role of the Media in Promoting and Reducing Tobacco Use, 2008. http://www.cancercontrol.cancer.gov/tcrb/ monographs/19/m19 7.pdf (accessed 1 Aug 2011).

7. Questions and Answers on Tobacco Advertising. Europa Press Release Rapid. http://europa.eu/rapid/pressReleasesAction.do?reference=MEMO/05/ $274 \&$ format $=$ HTML\&aged $=0$ \&language $=$ EN\&guilanguage $=$ en $($ accessed 5 Nov 2010)

8. Anon. Ferrari refutes subliminal tobacco advertising claim. GP Week 2010;80:9. http://mag.gpweek.com/?iid=35869 (accessed 5 Nov 2010).

9. Grant-Braham B. An investigation into Motorsport Sponsorship: A Comparative Analysis of Two and Four Wheeled Sponsorship. PhD Thesis. Bournemouth University. 2009. http://eprints.bournemouth.ac.uk/12329/ (accessed 2 Aug 2010).

10. Anderson SJ, Dewhirst T, Ling PM. Every document and picture tells a story: using internal corporate document reviews, semiotics, and content analysis to assess tobacco advertising. Tob Control 2006;15:254-61.

11. Hilton C. Grand Prix Century. Yeovil, UK: Haynes Publishing, 2005:285

12. FIA. Centenary Book, 2004:127. http://www.fia.com/mediacentre/100_Years/ fia_centenary.html\# (accessed 18 Jul 2005).

13. H2g2. Colin Chapman and Lotus Cars, 2007. http://www.bbc.co.uk/dna/h2g2/ A827598 (accessed 2 Jan 2007).

14. Howard A. Behind the Scenes in Motor Racing. London: Partridge Press, 1992:46-53.

15. Henry A. Williams - the Business of Grand Prix Racing. Yeovil: Patrick Stephens Ltd., 1991:84.

16. Foxall GR, Johnston BR. Innovation in Grand Prix motor racing: the evolution of technology, organization and strategy. Technovation 1991;11:387-402.

17. Eastoe B. Still in with a sporting chance. Accountancy 1994:1215:34-7.

18. Parsons A. Formula one plan to quit Europe. The Sunday Times 1997:2.9

19. Roebuck N. Little Big Man. Autocourse 2005-2006. Silverstone, UK, Crash Media Group Ltd., 2006:24-9.

20. Vaezi S. 24 month Cycle Planning Meeting, 1997. http://legacy.library.ucsf.edu/tid/ hcq53a99/pdf (accessed 22 Jun 2010).

21. BAT. Budget for SE 555 1998, 1998. http://legacy.library.ucsf.edu/tid/ptn93a99 (accessed 12 Jul 2010).

22. Verlinden J. Dark Market Thailand, 1998. http://legacy.library.ucsf.edu/tid/ xno93a99/pdf (accessed 22 Jun 2010).

23. BAT. Silk Cut-Dark Markets, 2005. http://legacy.library.ucsf.edu/tid/npd04a99/pdf (accessed 22 Jun 2010).

24. NCI Monograph 19. The Role of the Media in Promoting and Reducing Tobacco Use, 2008:68. http://www.cancercontrol.cancer.gov/tcrb/monographs/19/m19_3. pdf (accessed 20 Apr 2011).

25. BAT. Going Dark European Taskforce, 1999. http://legacy.library.ucsf.edu/tid/ rxw92a99/pdf (accessed 22 Jun 2010).
26. BAT. Dark Market Checklist, 1999. http://legacy.library.ucsf.edu/tid/xdp04a99/pdf (accessed 22 Jun 2010)

27. BAT. Advertising Restrictions, 1999. http://legacy.library.ucsf.edu/tid/khx50a99/pdf (accessed 22 Jun 2010)

28. Philip Morris. Motorsport Sponsorship Marketing Review, 1992. http://legacy library.ucsf.edu/tid/noi22e00 (accessed 29 Jun 2010).

29. Philip Morris. N403, 1995. http://legacy.library.ucsf.edu/tid/ovo57d00 (accessed 5 Jul 2010).

30. Philip Morris International. F1 and Bikes Evaluation-Australia, 1993. http:// legacy.library.ucsf.edu/tid/fyw32e00 (accessed 5 Jul 2010).

31. Lambert A, Sargeant JD, Glantz SA, et al. How Philip Morris unlocked the Japanese cigarette Market: lessons for global tobacco control. Tob Control 2004;13:379-87.

32. Henry A. Philip Morris Extends Deal with Ferrari Despite Tobacco Ban, 2005. http:// sport.guardian.co.uk/formulaone/story/0,00.html,10069,1562831 laccessed 5 Sep 2005).

33. F1 Colours. http://f1colours.wordpress.com/2010/01/11/lesser-spotted-f1-liveries/ (accessed 19 Apr 2011).

34. Philip Morris. Marketing Research Department Report - European Name Test, 1986. http://legacy.library.ucsf.edu/tid/xsk93e00 (accessed 5 Jul 2010).

35. Schmidt P. Brand Name Development, 1986. http://legacy.library.ucsf.edu/tid/ qub78a00 (accessed 8 Jul 2010)

36. Krut A. Designer Name Awareness and Association Test-Ferrari, 1986. http:// legacy.library.ucsf.edu/tid/mhm87a00 (accessed 12 Jul 2010).

37. Krut A. Marketing Research Department Report, Designer Name Awareness and Association Test: Ferrari, Cartier, Dunhill, 1986. http://legacy.library.ucsf.edu/tid/ hlw93e00 (accessed 8 Jul 2010).

38. Tso D. Ferrari Project, 1987. http://legacy.library.ucsf.edu/tid/rat50b00 (accessed 8 Jul 2010).

39. Tso D. 87000 New Brand Development Strategy, 1987. http://legacy.library.ucsf. edu/tid/vst60b00 (accessed 8 Jul 2010)

40. Tso D. Ferrari-Preliminary Development Strategy, 1986. http://legacy.library.ucsf. edu/tid/gki60b00 (accessed 8 Jul 2010).

41. Philip Morris. Market Research Report, 1986. http://legacy.library.ucsf.edu/tid/ qiv06e00 (accessed 8 Jul 2010).

42. Philip Morris. Pan European Racing Awareness-820000 Table 6A-Spontaneous Awareness of Grand Prix motor racing cars—All male smokers, 1982. http://legacy. library.ucsf.edu/tid/ywf11b00 (accessed 1 Nov 2010).

43. Philip Morris. Proposed comments on Italy objectives 910000, 1991. http://legacy. library.ucsf.edu/tid/hpy32e00 (accessed 1 Nov 2010).

44. Philip Morris. Adaptation Marketing Plan, 1992. http://legacy.library.ucsf.edu/tid/ bvu22e00 (accessed 1 Nov 2010).

45. O'Rourke BJ. Draft Letter from Paul. Hastings: Janofsky \& Walker, 1997. http:// legacy.library.ucsf.edu/tid/ofa74a00/pdf (accessed 22 Jun 2010).

46. Landau D. Trade Marks Act, 1994. In the matter of application No 2364231 by Gallaher Limited to register the trade marks (A series of 4) in Class 34 and the opposition thereto under No 92905 by Philip Morris Products SA, 2007:5-16. http:// www.ipo.gov.uk/017507.pdf (accessed 22 Jun 2010).

47. IPO. Case details for Trade Mark 755171, 1956. http://www.ipo.gov.uk/t-findnumber?detailsrequested $=C$ Gtrademark $=755171$ (accessed 21 Jun 2010)

48. IP0. Case details for Trade Mark 1027148, 1974. http//www ipo gov uk/t-findnumber?detailsrequested $=$ Cqtrademark=1027148 (accessed 21 Jun 2010)

49. IPO. Case details for Trade Mark 1046101, 1975. http://www.ipo.gov.uk/t-findnumber?detailsrequested $=$ Cqtrademark=1046101 (accessed 22 Jun 2010).

50. IP0. Case details for Trade Mark 1176895, 1982. http://www.ipo.gov.uk/types/tm/tos/t-find/t-find-number?detailsrequested=C\&trademark=1176895 (accessed 22 Jun 2010).

51. Autocourse 1976-7. Surrey, UK: Hazleton Securities Limited, 1976:146.

52. ASH. Voluntary agreement on sponsorship of sport by tobacco companies in the UK, 1995. http://www.ash.org.uk/files/documents/ASH_170.pdf (accessed 20 Nov 2010).

53. Philip Morris. Agreement, 1993:4. http://legacy.library.ucsf.edu/tid/mwy72e00/pdf (accessed 22 Jun 2010)

54. BAT. BAT / Lucky Strike: Formula One-A Global Opportunity, 1999. http://legacy. library.ucsf.edu/tid/fno93a99 (accessed 27 May 2010).

55. BAT. Report regarding Lucky Strike, 1999. http://legacy.library.ucsf.edu/tid/ibq04a99 (accessed 25 May 2010).

56. Verlinden J. BAT Briefing PR: Briefing Document Prepared for Edelman, 1998 http://legacy.library.ucsf.edu/tid/ssc65a99 (accessed 27 May 2010).

57. Verlinden J. Lucky Strike Briefing Alternative Branding, 1999. http://legacy.library. ucsf.edu/tid/hgn93a99 (accessed 27 May 2010).

58. BAT. Lucky Strike Formula 1 strategy, 1999. http://legacy.library.ucsf.edu/tid/ ebq04a99 (accessed 27 May 2010).

59. Scuderia Ferrari. Press release: Scuderia Ferrari and Philip Morris International Sponsorship, 2010. http://www.ferrari.com/English/News/Formula-1/Pages/ 100429 F1 Scuderia Ferrari partnership Philip Morris.aspx laccessed 29 Apr 2010)

60. Autosport.com. Ferrari denies subliminal Marlboro livery, 2010. http://www. autosport.com/news/report.php/id/83194 (accessed 8 Jun 2010).

61. Tobacco.org, 1996. http://www.tobacco.org/News/96.01_tob_news.htm (accessed 28 Oct 2010).

62. Assunta M, Chapman S. The tobacco industry's accounts of refining indirect tobacco advertising in Malaysia. Tob Control 2004;13:ii63-70. 
63. Irish Marketing Journal (IMJ) A-Z of Marketing Terms. http://www.adworld.ie/ knowledgecentre/read?id=cd2b127b-12a5-4238-86dc-e3f91c2549e5 laccessed 20 Apr 2011).

64. Anon. Marlboro: one more year. GP Week 2010;85:10-11. http://mag.gpweek. com/?iid=37010\# (accessed 2 Aug 2010)

65. WHO Framework Convention on Tobacco Control. http://www.who.int/fctc/ text download/en/index.html (accessed 19 Apr 2011).

66. Physicians for a Smoke-Free Canada. How Tobacco Advertising Works, 2002. http://www.smoke-free.ca/pdf 1/adbrochure-howadswork.pdf (accessed 21 Apr 2011).

67. Haslam M. Benson and Hedges and Formula One Sponsorship, 1997. http://www tobaccopapers.com/PDFs/0500-0599/0576.pdf (accessed 12 Jul 2010)

68. F1 Racing Magazine. Marlboro F1 goes subliminal. Teddington, Midddlesex: Haymarket Publishing, April 2005:30.
69. Wakefield M, Morley CP, Horan JK, et al. The cigarette pack as image: new evidence from tobacco industry documents. Tob Control 2002;11(Suppl 1): i73-80.

70. Dewhirst T, Hunter A. Tobacco sponsorship of Formula One and CART auto racing: tobacco brand exposure and enhanced symbolic imagery through co-sponsors' third party advertising. Tob Control 2002:11:146-50.

71. Noble J. Ferrari Removes Bar Code Design. Autosport.com, 2010. http://www. autosport.com/news/report.php/id/83346 (accessed 8th Jun 2010)

72. Hay-Nicholls A. The Ferrari smoke screen. GP Week 2010;80:19-20. http://mag gpweek.com/?iid=35869 (accessed 2 Aug 2010).

73. Scuderia Ferrari official website. http://www.ferrari.com/English/Formula1/Partners/ Sponsors/Philip Morris International/Pages/PMl.aspx (accessed 20 Apr 2011).

74. Blum A. Tobacco in sport: an endless addiction? Tob Control 2005;14:1-2. 